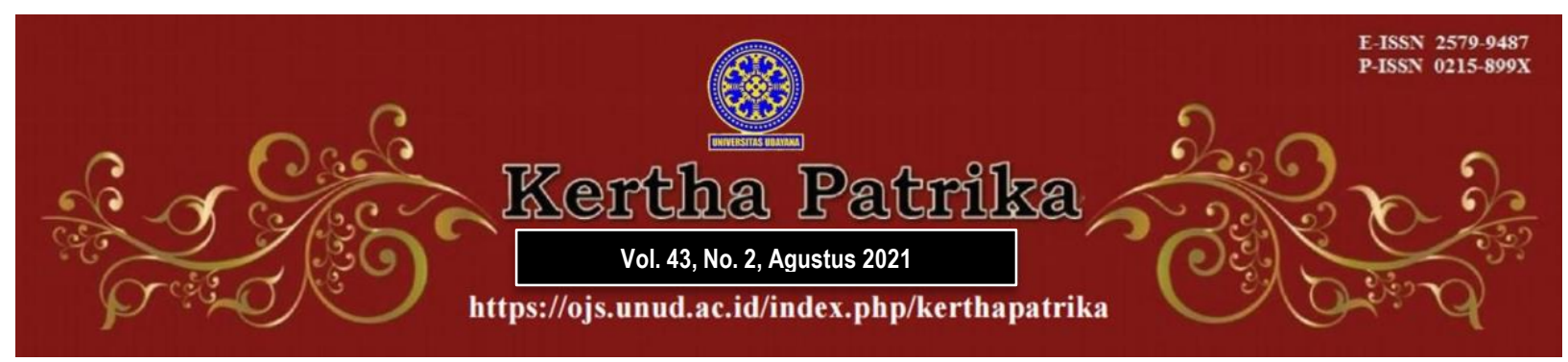

\title{
Kekayaan Intelektual di Kepulauan Bangka Belitung; Studi Terhadap Upaya Proteksi
}

\section{Darwance $^{1}$,Yokotani ${ }^{2}$, Wenni Anggita ${ }^{3}$}

${ }^{1}$ Fakultas Hukum Universitas Bangka Belitung, E-mail: darwance@yahoo.co.id

2 Fakultas Hukum Universitas Bangka Belitung, E-mail: yokotanimayo@gmail.com

${ }^{3}$ Fakultas Ekonomi Universitas Bangka Belitung, E-mail: wenni_anggita@ubb.ac.id

\begin{tabular}{l}
\hline Info Artikel \\
\hline Masuk : 26 April 2021 \\
Diterima : 21 Juni 2021 \\
Terbit : 1 Juli 2021 \\
Keywords : \\
Intellectual Property; Bangka \\
Belitung Islands; Protection \\
Measures \\
\\
\\
\\
Kata kunci: \\
Kekayaan Intelektual; \\
Kepulauan Bangka Belitung; \\
Upaya Proteksi \\
Corresponding Author: \\
Darwance, E-mail: \\
darwance@yahoo.co.id \\
DOI : \\
10.24843/KP.2021.v43.i02.p04 \\
\end{tabular}

\begin{abstract}
Referring to the object of protection from several laws and regulations in the field of intellectual property rights which some of them are in region, especially geographical indication, traditional knowledge, and cultural arts. The diversity of natural resources, art and culture in Bangka Belitung Islands Province also has potential to get legal protection. The objectives of this research are to know and analyze the protection effort of intellectual property in Bangka Belitung Province, either registerred normatively or some potential object which are registerred as protected intellectual property. A study of the protection of ntellectual property in Bangka Belitung Province uses juridical empirical research method with legal approach. The results of this study indicate that some efforts have been done to increase the protection on IPR in this region; some of them are increasing intellectual property registration through increasing cooperation with local governments, intellectual property and community centers. Several regional organizations in regional governments are also asked to propose IPR.
\end{abstract}


kekayaan intelektual melalui peningkatan kerjasama dengan pemerintah daerah, sentra kekayaan intelektual dan komunitas. Beberapa organisasi perangkat daerah di lingkungan pemerintah daerah juga diminta untuk mengusulkan KI.

\section{Pendahuluan}

Dibandingkan dengan makhluk hidup yang lain, manusia memiliki sesuatu membuatnya berbeda. Manusia pada eksistensinya merupakan mahluk hidup yang memiliki keistimewaan dan kemampuan yang sangat berkembang, sehingga membuat manusia dapat menyelidiki hal-hal mendalam terkait segala sesuatu yang dapat digunakan untuk kehidupannnya. ${ }^{1}$ Sebagai makhluk yang diciptakan oleh Tuhan, manusia dianugrahi dengan berbagai potensi sehingga eksistensinya tentu berbeda dengan makhluk lain sesame ciptaan Tuhan. Beberapa contoh di antaranya adalah manusia dibekali dengan akal. Dengan adanya akal inilah manusia kemudian dituntut tanggung jawabnya sebagai penerima amanah untuk menjaga dan mengelola apa pun yang ada di muka bumi. ${ }^{2}$

Sebagai satu-satunya makhluk ciptaan Tuhan yang diberikan anugerah berupa alat kelengkapan yang sempurna, yakni berupa akal dan juga budi, pada tahapan berikutnya manusia pun memiliki kemampuan untuk berkarya cipta tentang sesuatu yang diinginkan, seperti menciptakan ilmu pengetahuan, seni, termasuk pula teknologi yang sangat bernilai serta memberikan manfaat bagi kehidupan manusia. ${ }^{3}$ Manusia dengan demikian adalah makhluk yang memiliki akal (rasio). Akal inilah yang membedakan manusia dari makhluk-makhluk yang lain. Hal ini didasari faktas bahwa manusia dapat menciptakn atau menghasilkan sesuatu, invensi (temuan) atau kreasi seperti benda-benda, ilmu pengetahuan dan juga seni. ${ }^{4}$ Selain itu, manusia juga mampu menemukan atau menciptakan teknologi baru, atau memperbaharui teknologi yang sebelumnya sudah ada.

Suatu karya yang kemudian lahir dalam praktik sudah barang tentu menghabiskan tenaga, waktu, dan termasuk biaya, sehingga menjadikan karya menjadi bernilai. Hak ini disebabkan oleh adanya manfaat atau nilai ekonomi yang terkandung pada suatu karya kreasi seorang manusia, maka lahirlah konsepsi tentang kekayaan yang pada gilirannya diikuti oleh tumbuhnya konsepsi hukum tentang hak. Lalu, lahir pula kebutuhan untuk melindungi kekayaan itu. ${ }^{5}$ Salah satunya dirumuskan sebagai property

1 Babutta, S.L., (2020), Memaknai Manusia dalam Dimensi Mahluk Hidup: Kajian Filosofis dari Sudut Pandang Biologi, Jurnal Filsafat Indonesia, 3 (2), doi: http://dx.doi.org/10.23887/jfi.v3i2.22512, p. 48.

2 Yuhaswita, (2016), Akal, Manusia dan Kebudayaan, Tsaqofah $\mathcal{E}$ Tarikh, 1 (1), doi: http://dx.doi.org/10.29300/ttjksi.v1i1.861, p. 18.

3 Riswandi, B.A. dan Syamsudin, M. (2004). Hak Kekayaan Intelektual dan Budaya Hukum. Jakarta: RajaGrafindo Persada. p. 187

4 Dirdjosisworo, S. (2005). Antisipasi Terhadap Bisnis Curang; Pengalaman Negara Maju Dalam Perlindungan Hak Kekayaan Intelektual (Intellectual Property) dan Pengaturan E-Commerce Serta Penyesesuaian Undang-Undang HKI Indonesia. Bandung: CV. Utomo. p. 105.

5 Margono, M. (2010). Hukum Hak Cipta Indonesia; Teori dan Analisa Harmonisasi Ketentuan WTOTRIPs Agreement. Bogor: Ghalia Indonesia. p. 51. 
rights atau kekayaan intelektual (KI), di mana wujud perlindungan hukum bersifat eksklusif dan pemberian penghargaan yang setinggi-tingginya. ${ }^{6}$

Secara teoritis, KI dibagi menjadi dua. Pertama, hak milik perindustrian (industrial property rights), meliputi di antaranya adalah paten (patents), merek (trademarks), desain industri (industrial design), dan lain-lain. Kedua, hak cipta (copyrights). Hak cipta dibedakan lagi menjadi dua, yakni hak cipta (atas seni, sastra, dan ilmu pengetahuan) dan hak-hak yang terkait dengan hak cipta (neigbouring rights). ${ }^{7}$ Perbedaan pokok antara keduanya terletak pada dasar lahirnya perlindungan. Pada hak milik perindustrian, perlindungan lahir karena adanya kedaulatan negara. Artinya, secara faktual perlindungan hukum terhadap hak milik perindustrian baru dianggap berlaku sejak negara memberikan pengakuan atas hak tersebut. Oleh sebab itu, pendaftaran hak milik industri merupakan suatu keharusan yang menjadi dasar perlindungan dimaksud kemudian hari. Hal ini tentu berbeda dengan hak cipta mengenal asas perlindungan otomatis (automatical protection). ${ }^{8}$

Hak kekayaan intelektual (KI) seringkali diabaikan, dan baru mendapatkan perhatian serius apabila sesuatu yang pada dasarnya mengandung unsur KI di dalamnya terjadi sengketa. Perkembangan massif yang terjadi pada ilmu pengetahuan dan teknologi mutakhir ini menjadikan KI semakin penting untuk dilindungi. Sejak konsepnya disampaikan beberapa ratus tahun silam, KI sebetulnya sudah menjadi sesuatu yang bukan hanya sebagai simbol. Lebih dari itu, di dalam KI ada hak milik subjek hukum, yakni seseorang atau beberapa orang atau badan hukum, yang apabila hak itu dilanggar atau diklaim oleh pihak lain, sudah selayaknya ada upaya hukum yang bisa dilakukan. Pihak yang mengklaim selanjutnya pun bisa dikenakan sanksi.

Pada sejumlah literasi memang sulit dijumpai para ahli atau penulis buku yang menyampaikan makna KI melalui definisi berbentuk kalimat atau redaksi, di antaranya karena kesulitan untuk memberikan definisi secara tunggal tentang KI. KIakan lebih mudah dijelaskan dengan contoh-contoh langsung tentangnya yang ada dalam kehidupan sehari-hari. ${ }^{9}$ KI dengan demikian bukan cuma berada di satu tempat saja, tapi ada di tempat-tempat yang lain termasuk di daerah-daerah, terutama untuk jenis tertentu, misalnya ekspresi budaya tradisional, indikasi geografis, perlindungan varietas tanaman, dan lain sebagainya. Indikasi geografis misalnya yang hampir setiap tahun selalu ada peningkatan pendaftaran di Direktorat Jenderal KI Kementerian Hukum dan HAM Republik Indonesia. ${ }^{10}$

6 Sadikin, OK. (2004). Aspek Hukum Hak Kekayaan Intelektual. Jakarta: Rajagrafindo Persada. Jakarta. p. 56-57.

7 Hasibuan, O. (2006). Perlindungan Hak Ekonomi Pencipta Lagu dan Pemegang Hak Terkait di Indonesia (Ringkasan Desertasi). Yogyakarta: Universitas Gadjah Mada, p. 7.

$8 \quad$ Ibid., p. 8.

9 Darwance, Yokotani, \& Anggita, W. (2020). Dasar-Dasar Perlindungan Hak Kekayaan Intelektual. Progresif: Jurnal Hukum. doi: https://doi.org/10.33019/progresif.v15i2.1998. p. 196.

10 Karim. A dan Dayanto. (2016). Perlindungan Hukum dan Pengembangan Indikasi Geografis Minyak Kayu Putih di Pulau Buru. Jurnal RechtsVinding 5 (3). doi: http://dx.doi.org/10.33331/rechtsvinding.v5i3.151. p. 382. 
Di Kepulauan Bangka Belitung, sebagai contoh awal, Lada Putih Muntok (Muntok White Pepper) yang terdaftar oleh Badan Pengelola, Pengembangan dan Pemasaran Lada (BP3L) Provinsi Kepulauan Bangka Belitung dengan ID G 000000004 pada 28 April 2010, merupakan satu-satunya indikasi geografis terdaftar dari Kepulauan Bangka Belitung. ${ }^{11}$ Di sisi lain, daerah ini kaya akan potensi indikasi geografis, sebut saja Nanas Bikang, Nanas Badau, Nanas Tua Tunu, Durian Bangka, Madu Pelawan, dan lain sebagainya. Sementara itu, di beberapa daerah terutama terutama di kawasan Sumatera, banyak yang memiliki lebih dari satu indikasi geografis, seperti Aceh dengan 3 indikasi geografis, Sumatera Barat dengan 2 indikasi geografis, Sumatera Utara dengan 6 indikasi geografis, Sumatera Selatan dengan 3 indikasi geografis, dan Jambi dengan 3 indikasi geografis. Sumatera Selatan misalnya, berhasil mendaftarkan Kopi Robusta Semendo, Kopi Robusta Empat Lawang, dan Duku Komering. ${ }^{12}$ Minimnya indikasi geografis yang terdaftar, sementara potensi yang dimiliki cukup tinggi, tentu menjadi penting untuk dikaji lebih spesifik melalui penelitian ini.

Selain itu, beberapa kasus dalam konteks perlindungan terhadap kekayaan intelektual juga sempat terjadi di daerah ini. Pada tahun 2015 misalnya, Kepolisian Daerah Kepulauan Bangka Belitung pernah menangan kasus pelanggaran terhadap hak cipta yang dilakukan oleh diskotik dan karaoke Grand Millenium, Monalisa atau Alim, Venus, 32 Jebus dan Paradise.13 Selanjutnya pada tahun 2017, Direktorat Reserse Kriminal Khusus Kepolisian Daerah Kepulauan Bangka Belitung menetapkan John Sumampau, Direktur PT Sumampau Bangka Lestari, sebagai tersangka pelanggaran hak cipta terkait pembuatan video deskripsi keindahan alam Pulau Bangka. Perkara ini diawali dengan adanya laporan Muhammad Faturrahman, Direktur PT Lensa Babel, terhadap PT Sumampau Bangka Lestari selaku pengembang proyek properti Pasir Padi Bay Pangkalpinang atas penggunaan video milik PT Lensa Babel dalam iklan promosi Pasir Padi Bay. ${ }^{14}$ Sejumlah kasus pelanggaran terhadap kekayaan intelektual yang pernah terjadi mengindikasikan bahwa upaya proteksi terhadap kekayaan intelektual di daerah ini perlu dilakukan penelitian yang lebih merinci.

Berdasarkan hasil penelusuran yang sudah dilakukan, tidak banyak penelitian yang mengkaji tentang perlindungan KI di Kepulauan Bangka Belitung. Salah satu penelitian yang memfokuskan tentang perlindungan HK di daerah ini adalah penelitian yang dilakukan oleh Siti Nurhaini berjudul Perlindungan Hak Cipta Atas Ekspresi Budaya Tradisional Pada Kerajinan Tangan Di Provinsi Kepulauan Bangka Belitung. Lebih spesifik lagi, penelitian ini salah satunya mengkaji tentang tentang peran pemerintah daerah dalam perlindungan hak cita atas ekpresi budaya tradisional. Hasil yang dilakukan oleh Siti Nurhaini menunjukkan bahwa perlindungan hak cipta atas ekspresi

11 Darwance, Nugroho. S., \& Yokotani. (2018). Pengaturan Komoditas Lada di Provinsi Kepulauan Bangka Belitung Perspektif Asas-Asas Pembentukan Peraturan PerundangUndangan. Jurnal Kertha Patrika. 40 (1). DOI: https://doi.org/10.24843/KP.2018.v40.i01.p01. p. 5.

12 Lihat di www.dgip.go.id, (Diakses 09 Maret 2021).

13 Polda Babel Tangani 5 Kasus Pelanggar Hak Cipta.. Lihat di https://www.radarbangka.co.id/berita/detail/kamtibmas/28739/polda-babel-tangani-5-kasuspelanggar-hak-cipta.html, (Diakses 18 Mei 2021).

14 Gara-Gara Video Wisata Bos Ini Tersangka Kasus Hak Cipta. Lihat di https:// nasional.tempo.co/read/850151/gara-gara-video-wisata-bos-ini-tersangka-kasushak-cipta, (Diakses 18 Mei 2021). 
budaya tradisional sudah dilakukan oleh pemerintah daerah di wilayah ini. Beberapa upaya perlindungan yang sudah dilakukan di antaranya adalah dengan sejumlah sosialisasi, pencatatan, pengawasan, pelestarian, pembinaan serta menyelenggarakan pendaftaran terhadap warisan budaya tradisiona. Selain itu juga, disusunnya rancangan peraturan daerah (raperda) dan juga peraturan bupati (perbub) di daerah yang memiliki warisan budaya tradisional. ${ }^{15}$ Itu artinya dalam publikasi ini dikaji tentang peran yang sudah dilakukan oleh pemerintah daerah di Kepulauan Bangka Belitung, khususnya dalam melindungi ekspresi budaya tradisional. Jika penelitian yang dilakukan oleh Siti Nurhaini memfokuskan pada perlindungan ekspresi budaya tradisioanal, maka penelitian ini lebih umum pada upaya perlindungan kekayaan intelektual secara makro, meliputi seluruh cabang kekayaan intelektual yang ada.

Penelitian ini bertujuan untuk mengetahui sekaligus menganalis upaya proteksi terhadap kekayaan intelektual di Kepulauan Bangka Belitung, baik terhadap kekayaan intelektual yang secara normatif sudah terdaftar maupun upaya proteksi terhadap sejumlah objek yang berpotensi didaftarkan sebagai kekayaan intelektual yang dilindungi. Hal ini dilakukan untuk mengetahui lebih detail lagi persoalan yang dihadapi dalam upaya yang dilakukan untuk selanjutnya dapat dikonstruksikan upaya yang ideal agar kekayaan intelektual yang ada dapat betul-betul terlindungi. Oleh sebab itu, pada bagian pembahasan akan dikaji dimulai dari aspek pengaturan kekayaan intelektual yang berkaitan dengan kewenangan pemerintah, terutama pemerintah daerah. Pada bagian berikutnya, akan dikaji tentang sejumlah upaya proteksi yang sudah dilakukan, baik oleh Kantor Wilayah Kementerian Hukum dan Hak Asai Manusia Kepulauan Bangka Belitung maupun oleh Pemerintah Provinsi Kepulauan Bangka Belitung.

\section{Metode Penelitian}

Penelitian ini dilakukan berdasarkan metode penelitian yang bersifat yuridis empiris dengan pendekatan undang-undang. Oleh sebab itu, penelitian ini menganalisis dan mengkaji bekerjanya hukum di tengah-tengah masyarakat, khususnya lagi yang bertautan dengan kepatuhan terhadap hukum, bagaimana peran dari peranan lembaga/ institusi hukum dalam proses penegakan hukum, dan implementasi aturan hukum, ${ }^{16}$ serta penelitian terhadap efektivitas hukum. ${ }^{17}$ Hanya saja, dalam penelitian ini hanya akan dikaji tentang bagaimana peran dari peranan lembaga/ institusi hukum dalam proses penegakan hukum, dan implementasi aturan hukum. Langkah-langkah ini dilakukan untuk mengetahui tahapan bekerjanya hukum di dalam masyarakat.18 Data dalam penelitian ini merupakan data primer yang didapatkan dengan melakukan Focus Group Discussion (FGD). Data yang diperoleh kemudian diolah dengan metode analisis kualitatif.

15 Nurhaini, S. (2017). Perlindungan Hak Cipta Atas Ekspresi Budaya Tradisional Pada Kerajinan Tangan di Provinsi Kepulauan Bangka Belitung, Progresif: Jurnal Hukum. 10 (1). doi: https://doi.org/10.33019/progresif.v11i1.195. p. 1818.

16 Salim HS \& Nurbani, E.S. (2017). Penerapan Teori Hukum Pada Penelitian Tesis dan Disertasi. Jakarta: RajaGrafindo Persada. p. 20.

17 Soekanto, S. (2012). Pengantar Penelitian Hukum. Jakarta: UI Press. p. 51.

18 Nasution, B.J. (2008). Metode Penelitian Ilmu Hukum. Bandung: Mandar Maju. p. 123. 


\section{Hasil Dan Pembahasan}

\subsection{Perlindungan KI Oleh Pemerintah Perspektif Regulasi}

Di antara sesama manusia, terjalin hubungan yang dilatarbelakangi beragam kepentingan. Perbedaan kepentingan ini dalam situasi tertentu kemudian menimbulkan sengketa atau konflik. Segala bentuk aturan dengan demikian diperlukan agar terciptanya hubungan yang harmonis antara sesama manusia, di antaranya dengan hadirnya hukum dalam maknanya sebagai norma. Dengan adanya norma hukum, baik norma yang bersifat mengatur maupun norma yang bersifat memaksa, masyarakat dipaksa untuk menaatinya secara patuh sehingga terciptanya keseimbangan. ${ }^{19}$ Hukum dengan demikian hadir sebagai penyeimbang atau menjadi sarana dalam mengatur kehidupan manusia, termasuk apabila terjadi konflik dan sengketa.

Oleh Subekti dikatakan hukum itu acuannya adalah tujuan negara, yakni mendatangkan kemakmuran, termasuk di dalamnya mewujudkan tujuan negara dengan menyelenggarakan keadilan dan ketertiban. Sedangkan van Apeldoorn menyebutkan tujuan hukum itu untuk mengatur pergaulan hidup manusia secara damai dengan cara melindungi kepentingan-kepentingan hukum manusia tertentu, kehormatan, jiwa, harta benda terhadap pihak yang merugikannya. ${ }^{20}$ Dari dua tujuan hukum ini, paling tidak dapat disimpulkan bahwa hukum pada prinsipnya hadir agar terciptanya ketertiban dalam kehidupan manusia dengan cara memberikan perlindungan dalam beragam wujudnya.

Perlindungan hukum oleh Satjipto Raharjo adalah memberikan pengayoman terhadap hak asasi manusia (HAM), yakni HAM yang dirugikan orang lain, bertujuan agar dapat dinikmati semua hak-hak yang diberikan oleh hukum. ${ }^{21}$ Oleh Maria Theresia Geme, perlindungan hukum berkaitan dengan tindakan negara untuk melakukan sesuatu untuk memberikan jaminan kepastian hak-hak seseorang atau kelompok orang. Sementara itu, Salim HS \& Erlies Septiana Nurbani mengartikan perlindungan hukum adalah manifestasi dari hukum itu sendiri dalam upaya atau pelayanan yang diberikan kepada subjek hukum serta hal-hal yang menjadi objek yang diberikan perlindungan. ${ }^{22}$ Sebagaimana disampaikan oleh Philipus M. Hadjon, secara teoritis perlindungan hukum dibagi menjadi perlindungan yang bersifat preventif (pencegahan) dan represif (menyelesaikan bila terjadi sengketa). ${ }^{23}$ Jadi, dapat pula disampaikan bahwa perlindungan hukum merupakan upaya dalam menegakkan hak asasi subjek hukum dari tindakan-tindakan yang merugikan dirinya sebagai pemegang hak. Philip $\mathbf{M}$. Hadjon mengemukakan perlindungan hukum ada dua bentuk, yakni perlindungan hukum yang bersifat preventif yang bertujuan untuk menghindari perselisihan dan perlindungan hukum represif yang ditujukan untuk menyelesaikan perselisihan. ${ }^{24}$

19 Kansil, C.S.T. \& Kansil, C.S.T. (2011), Pengantar Ilmu Hukum Indonesia. Jakarta: Rineka Cipta. p. 36.

$20 \quad$ Ibid., p. 36-37.

21 Raharjo, S. (2000). Ilmu Hukum. Bandung: Citra Aditya Bhakti. p. 54.

22 Salim HS \& Nurbani, E.S., Op. Cit., p. 262.

23 Ibid., p. 264.

24 Anggraeni, D. \& Ahmad, P. (2018). Upaya Perlindungan Hukum Terhadap Indikasi Geografis di Kota Tangerang Selatan untuk Mengembangkan Ekonomi Masyarakat Lokal. Prosiding Seminar 
Pada dasarnya, negara merupakan sarana atau wadah bagi setiap unsur yang ada di dalamnya untuk mencapai tujuan bersama. Sebagaimana yang disampaikan oleh Plato, yakni bertujuan untuk memajukan kesusilaan manusia sebagai individu maupun manusia sebagai sebagai makhluk sosial.25 Tujuan negara Republik Indonesia salah satunya yang tercantum di dalam pembukaan Undang-Undang Dasar Negara Republik Indonesia Tahun 1945 (UUD NRI 1945), antara lain untuk melindungi segenap bangsa dan seluruh tumpah darah Indonesia, memajukan kesejahteraan umum, dan mencerdaskan kehidupan bangsa. Melindungi yang dimaksud di sini termasuk pula melindungi hak-hak warga negara, seperti hak milik, baik hak milik atas benda berwujud maupun benda tidak berwujud (seperti halnya KI).

Selain subjek hukum, dalam hukum dikenal pula objek hukum. Dalam hukum perdata, objek hukum adalah segala yang berguna bagi subjek hukum, baik itu manusia atau badan hukum, dan tentunya dapat menjadi objek dalam hubungan hukum, karena sesuatu itu dapat dikuasai oleh subjek hukum. ${ }^{26}$ Dalam kepustakaan perdata disebutkan, objek hukum adalah benda. ${ }^{27} \mathrm{Hal}$ ini ditarik dari terminologi benda yang merupakan terjemahan dari bahasa Belanda zaak dalam rumusan Pasal 499 KUH Perdata, yakni segala sesuatu yang dapat dihaki atau menjadi objek hak milik. ${ }^{28}$

Dalam kepustakaan hukum, dikenal 3 pengertian benda, yakni sebagai barang yang dapat dilihat atau berwujud, sebagai kekayaan seseorang yang berupa hak dan penghasilan., dan sebagai objek hukum. ${ }^{29}$ Dengan demikian, perspektif KUH Perdata, benda sebagai objek hukum tidak sebatas "benda yang berwujud", tetapi juga "benda tidak berwujud" (hak atas barang yang berwujud). Hak dalam konteks ini disebut juga sebagai bagian dari harta kekayaan (vermogensbestand deel). ${ }^{30}$ Berdasarkan konsep benda, dapat disimpulkan bahwa KI merupakan objek hukum yang dapat dimiliki (objek hak milik).

Secara filosofis, ada dua teori yang berkaitan dengan anggapan hukum bahwa KI adalah suatu sistem kepemilikan (property), masing-masing dikemukakan oleh John Locke dan Friedrich Hegel, yang secara prinsip menguatkan posisi bilamana seseorang atau beberapa orang atas kreasinya melahirkan sesuatu, apalagi kemampuan mengkreasikan itu tidak dimiliki oleh pihak lain, maka ia adalah pemilik hak. Oleh John Locke, konsep kepemilikan (property) dikaitkan dengan konsep hak asasi manusia (human rights), yakni dalam status naturalis (state of nature) suasana aman tenteram dan tidak ada hukum positif yang membagi kepemilikan atau pembagian wewenang seseorang tertentu untuk memerintahkan orang lain. Konsep seperti ini dikarenakan kepemilikan atau pembagian wewenang merupakan kewajiban moral atas perilaku seseorang terhadap

Ilmiah Nasional “Kearifan Lokal Untuk Menjawab Tantangan Global”. 27-28 Oktober 2018. p. 83.

25 Galih, Y.S. (2017). Kewajiban Negara Melindungi Anak Bangsa. Jurnal Nasional Galuh Justisi. 5 (1). doi: http://dx.doi.org/10.25157/iigj.v5i1.249. p. 7.

26 Tutik, T.T., (2015), Hukum Perdata Dalam Sistem Hukum Nasional, Jakarta: Kencana, p. 143.

27 Sofwan, S.S.M. (2000). Hukum Perdata: Hukum Benda. Yogyakarta: Liberty. p. 13.

28 Syahrani, R. (2013). Seluk-Beluk dan Asas-Asas Hukum Perdata. Bandung: Alumni. p. 107.

29 Salim HS. (2016). Pengantar Hukum Perdata Indonesia Tertulis (BW). Jakarta: Sinar Grafika. p. 96.

30 Muhammad, A. (2019). Hukum Perdata Indonesia. Bandung: Citra Aditya Bakti. p. 127. 
orang lain yang dibebankan oleh Tuhan. ${ }^{31}$ Inilah yang disebutkan hak alamiah. Hal alamiah dalam banyak hal, termasuk dalam konteks KI, dimaknai sebagai sesuatu yang diciptakan oleh seseorang atau beberapa orang, maka secara alami sekalipun tanpa adanya hukum positif yang mengaturnya, maka ialah sebagai pemilik hasil ciptaan itu. ${ }^{32}$

Dalam konteks pembenaran KI, Friedrich Hegel yang mengembangkan konsep rights, ethic, and state, mengartikan kepemilikan sebagai antara lain cara di mana seseorang individu dapat secara objektif mengungkapkan keinginan pribadi dan tunggal. Menurutnya, suatu kekayaan (property) pada suatu tahap tertentu harus menjadi hal yang bersifat pribadi (private) dan kekayaan pribadi (privateproperty) harus menjadi lembaga yang bersifat universal. Dalam kekayaan (property), ada sesuatu yang lebih dari sekadar perilaku insting manusia, yakni salah satu cara untuk membangun atau menetapkan batas-batas antara pribadi dan kekayaan lain dari masyarakat, yakni dalam bentuk penghargaan pada KI.33

Perkembangan teori yang berkaitan dengan perlindungan KI di antaranya dipengaruhi adanya kebutuhan dalam rangka penyelesaian sengketa hukum di pengadilan ataupun dalam hal perjanjian perdagangan internasional, termasuk agar KI selalu dapat mengikuti perkembangan zaman. Ada beberapa teori yang dijadikan landasan dari perlindungan KI antara lain Teori Hak Alami, Teori Karya, Teori Pertukaran Sosial, dan Teori Fungsional Perspektif teori-teori ini, kepemilikan atas KI termasuk dalam Hak Asasi Manusia sebagai Individu yang berpola pikir sehingga KI dalam teori-teori diatas memberikan perlindungan terhadap individu pemilik KI agar hak-haknya tidak dilanggar oleh orang lain. ${ }^{34}$

Menurut Robert C Sherwood, terdapat 5 teori dasar perlindungan KI, yakni reward theory, recovery theory, incentive theory, risk theory, dan economic growth stimulus theory. ${ }^{35}$ Menurut reward theory, pencipta atau penemu yang akan diberikan perlindungan perlu diberikan penghargaan atas usaha atau upaya tersebut. 36 Sementara itu, recovery theory bahwa penemu atau pencipta atau pendesain yang telah membuang waktu, biaya serta tenaga untuk menghasilkan karya intelektualnya perlu diberikan semacam kesempatan untuk meraih kembali apa yang telah dikeluarkannya. ${ }^{37}$ Incentive theory mengatakan

31 Nasution, R.J.P. (2017). Interface Hukum Kekayaan Intelektual dan Hukum Persaingan Usaha (Penyalahgunaan HKI). Depok: RajaGrafindo Persada. p. 24.

32 Darwance, Yokotani, \& Anggita, W., Op. Cit., p. 201-202.

33 Nasution, R.J.P., Op.Cit., p. 26-29.

34 Mike, E. (2017). Perlindungan Hukum Hak Kekayaan Intelektual Terhadap Tindakan Pelanggaran Pembajakan Buku Elektronik Melalui Media Online. AL-IMARAH: Jurnal Pemerintahan dan Politik Islam. 2 (2). doi: http://dx.doi.org/10.29300/imr.v2i2.1449. p. 137138.

35 Nizwana, Y. \& Rahdiansyah. (2019). Perlindungan Hak Kekayaan Intelektual (HAKI) Ditinjau Dari Epistimologi. UIR Law Review. 3 (2), doi: https://doi.org/10.25299/uirlrev.2019.vol3(02).4006. p. 36.

36 Mahardhita, Y \& Sukron, A.Y. (2018). Perlindungan Hukum Hak Kekayaan Intelektual Melalui Mekanisme "Cross Border Measure". Jurnal Ilmiah Ilmu Hukum QISTIE. 11 (1). doi: http://dx.doi.org/10.31942/jqi.v11i1.2227. p. 93-94.

37 Nurdahniar, I. (2016). Analisis Penerapan Prinsip Perlindungan Langsung Dalam Penyelenggaraan Pencatatan Ciptaan. veritas et Justitia. 2 (1). doi: https://doi.org/10.25123/vej.v2i1.2073. p. 232-233. 
bahwa insentif perlu diberikan agar kegiatan-kegiatan pelaksanaan dan pengembangan kreatifitas penemuan dan semangat untuk menghasilkan penemuan baru dapat terjadi. ${ }^{38}$ Risk theory risk theory menyatakan bahwa KI yang merupakan hasil penelitian mengandung risiko yang memungkinkan orang lain yang terlebih dahulu menemukan cara tersebut atau memperbaikinya sehingga perlindungan hukum yang diberikan terhadap upaya atau kegiatan yang mengandung risiko tersebut merupakan hal yang wajar harus ada. ${ }^{39}$ Economic growth stimulus theory perlindungan terhadap HaKI merupakan suatu alat pembangunan ekonomi yaitu keseluruhan tujuan dibangunnya suatu sistem perlindungan KI yang efektif ${ }^{40}$ Oleh sebab itu, perlindungan hukum terkait KI bagi penemu atau pencipta atas karya intelektual yang telah dihasilkan, dilakukan agar penemu atau pencipta mendapatkan hak-haknya. Hak yang dimaksud baik berupa moral maupun hak ekonomi, serta yang lain yang melekat di dalamnya. Selain itu, perlindungan diberikan sebagai wujud penghargaan atas kerja keras, pengorbanan waktu dan tenaga, serta biaya untuk menghasilkan karya intelektual yang mengandung unsur inovasi. 41

Selain itu, perlindungan terhadap KI juga diberikan atas dasar permikiran bahwa reputasi yang dibangun oleh pihak-pihak tertentu, harus diberikan perlindungan atas usahanya dalam membangun reputasi yang dimaksud. ${ }^{42}$ Dasar pemikiran lain yang menjadi pembenaran pemberian perlindungan KI adalah nilai ekonomi yang ada pada KI sebagai hak kepemilikan atas benda.43 KI dalam konteks ini adalah wujud kompensasi sekaligus menjadi dorongan bagi orang dalam menciptakan atau menemukan sesuatu. ${ }^{44}$ Sebagaimana dikatakan oleh Rahmi Jened Parinduri Nasution, sistem penghargaan seperti ini memberikan hak eksklusif yang merupakan monopoli yang bersifat terbatas sekaligus menjadi pembatas antara pemegang hak dengan pesaingnya, sehingga pemegang KI dapat mengeksploitasi haknya dan menikmati manfaat finansial yang ada. 45

Pada akhirnya, dapat dikatakan bahwa negara memiliki kewajiban dalam melindungi hak setiap warga negara, di antaranya melalui sejumlah peraturan perundangundangan. Oleh sebab itu, sejumlah regulasi yang mengatur tentang KI, secara berkala dikeluarkan oleh pemerintah dalam rangka memberikan perlindungan terhadap hasil olah intelektual subjek hukum, baik manusia maupun badan hukum. Pengaturan yang dimaksud dan yang sedang berlaku saat ini adalah hak cipta yang diatur dalam

38 Umami, Y.Z. \& Roisah. K. (2015). Perlindungan Hukum Terhadap Kelapa Kopyor Sebagai Potensi Komoditas Indikasi Geografis Kabupaten Pati. Jurnal Law Reform. 11 (1). doi: https://doi.org/10.14710/lr.v11i1.15760. p. 116-117.

39 Panduwinata, B. (2013). Perlindungan Hukum Hak Cipta Bagi Pengarang Buku (Legal Protection Of The Copyright For The Author Of The Book) (Tesis). Program Pascasarjana Magister Kenotariatan Universitas Hasanuddin Makassar. p. 58-59.

40 Sari, N.K. \& Susanti, D.O, Perlindungan Hukum Bagi Pemilik Karya Cipta Batik Tulis Dewi Rengganis di Desa Jatiurip Kecamatan Krejengan Kabupaten Probolinggo. SASI. 24 (2). doi: https://doi.org/10.47268/sasi.v24i2.127. p. 126-128.

41 Ibid.

42 Lindsey, T., Damian, E., Butt, S. \& Utomo, T.S. (2013). Hak Kekayaan Intelektual Suatu Pengantar. Bandung: Alumni. p. 14.

43 Nasution, R.J.P., Op. Cit., p. 35.

44 Lindsey, T., Damian, E., Butt, S. \& Utomo, T.S., Loc. It.

45 Nasution, R.J.P., Op. Cit., p. 37. 
Undang-Undang Nomor 28 Tahun 2014, paten yang diatur dalam Undang-Undang Nomor 13 Tahun 2016, rahasia dagang yang diatur dalam Undang-Undang Nomor 30 Tahun 2000, merek dan indikasi geografis yang diatur dalam Undang-Undang Nomor 20 Tahun 2016, desain industri yang diatur dalam Undang-Undang Nomor 31 Tahun 2000, dan desain tata letak sirkuit terpadu yang diatur dalam Undang-Undang Nomor 32 Tahun 2000, serta perlindungan terhadap varietas tanaman yang diatur dalam Undang-Undang Nomor 29 Tahun 2000.

Diterbitkannya regulasi yang secara spesifik mengatur tentang bidang-bidang KI ini, sekaligus menunjukkan adanya peran negara dalam upaya perlindungan terhadap KI itu sendiri, utamanya berbentuk preventif dalam wujud regulasi. Negara dengan demikian secara otomatis tidak cukup hanya menerbitkan regulasi saja, lebih dari itu adalah bagaimana supaya ketentuan-ketentuan yang ada di dalamnya betul-betul diimplementasikan, misalnya yang berkaitan dengan peran negara melalui kementerian atau lembaga sesuai bidangnya masing-masing dalam melindungi KI. Dalam konteks $\mathrm{KI}$, tentu ada peran negara melalui Kementerian Hukum dan Hak Asasi Manusia dan Kementerian Pertanian (khusus perlindungan terhadap varietas tanaman). Dua kementerian ini masing-masing memiliki representasinya di daerah, baik kantor wilayah maupun badan atau dinas-dinas di tingkat provinsi maupun kabupaten/ kota. Negara yang dimaksud dalam konteks ini bukan hanya pemerintah di pusat saja, tetapi juga pemerintah yang ada di daerah-daerah atau pemerintah daerah.

Pada setiap regulasi yang mengatur tentang $\mathrm{KI}$, sebagaimana yang sudah disebukan di atas, ada tanggungjawab pemerintah, baik secara implisit maupun eksplisit dijabarkan. Hanya saja, tidak semua undang-undang tentang KI yang memberikan kewenangan kepada pemerintah daerah. Pembentuk undang-undang menghendaki adanya keterlibatan pemerintah daerah dalam Undang-Undang Nomor 20 Tahun 2016 tentang Merek dan Indikasi Geografis, terutama pasal-pasal yang khusus mengatur tentang indikasi geografis.

Pasal 53 Undang-Undang Nomor 20 Tahun 2016 tentang Merek dan Indikasi Geografis disebutkan indikasi geografis dilindungi setelah didaftar oleh menteri. Menteri yang dimaksud di sini adalah Menteri Hukum dan Hak Asasi Manusia (HAM). Pengajuan permohonan salah satunya bisa juga dilakukan oleh pemerintah daerah, yakni pemerintah provinsi atau pemerintah kabupaten kabupaten/ kota. Di samping itu, dalam perlindungan indikasi geografis pemerintah daerah selain sebagai pemohon juga memiliki peran dalam hal pembinanan dan pengawasan, sesuai dengan ketentuan Pasal 70 Ayat (1) dan Ayat (2).46

\subsection{Upaya Perlindungan KI di Kepulauan Bangka Belitung}

Sebagaimana yang sudah diuraikan sebelumnya, diberikannya perlindungan secara hukum terhadap hasil kreasi seseorang atau beberapa orang didasari atas beberapa hal, di antaranya adalah hak alamiah yang melekat kepada pencipta atau penemu, perlindungan terhadap reputasi yang sudah dibangun dengan waktu yang lama dan

46 Darwance, Yokotani, \& Anggita, W. (2021). Politik Hukum Kewenangan Pemerintah Daerah Dalam Pengaturan Hak Kekayaan Intelektual. Journal of Political Issues. 2 (2). doi: https://doi.org/10.33019/jpi.v2i2.40. p. 130-131. 
biaya yang cukup tinggi, serta sebagai bentuk kompensasi dan dorongan bagi orang untuk mencipta atau menemukan sesuatu. Oleh sebab itu, sudah seharusnya seseorang yang karena kemampuan intelektualnya, olah pikir atau kreativitasnya dalam menciptakan dan menemukan sesuatu dan itu bermanfaat bagi masyarakat, dapat dinikmati secara massal, diberikan perlindungan dengan konsekuensi siapa pun yang menggunakan hasil ciptaan dan temuan itu harus mendapatkan izin terlebih dahulu. Izin ini dalam praktik berimplikasi pada kompensasi dalam bentuk royalti.

Di sisi lain, sesuai dengan kewenangan yang dimiliki, sekalipun tidak disebutkan secara eksplisit di dalam setiap undang-undang bidang KI, pemerintah daerah dapat mendorong masyarakat melalui organisasi perangkat daerah, untuk melakukan pendaftaran apabila ada hasil kreasi yang berpotensi diberikan perlindungan. Selain pemerintah daerah, Kementerian Hukum dan Hak Asasi Manusia melalui kantor wilayah di daerah pun harus berperan aktif dalam mendorong didaftarkannya KI oleh pihak-pihak yang berkepentingan untuk itu, terutama pencipta, inventor, dan pihakpihak lainnya. Upaya ini selanjutknya bukan hanya bermuara pada kepentingan hukum saja, lebih dari itu adalah nilai-nilai ekonomi yang secara langsung atau tidak berdampak positif terhadap roda perekonomian masyarakat di daerah.

Pada penelitian ini, dikaji upaya perlindungan yang dilakukan oleh Kantor Wilayah Kementerian Hukum dan Hak Asai Manusia Kepulauan Bangka Belitung dan Pemerintah Daerah Provinsi Kepulauan Bangka Belitung. Dua instansi instansi ini dipilih karena menjadi pihak yang terlibat langsung dalam perlindungan KI di daerah, terutama dalam memberikan edukasi dan dorongan kepada public untuk menghargai KI dan mendaftarkan KI. Upaya yang dilakukan oleh Kantor Wilayah Kementerian Hukum dan Hak Asai Manusia Kepulauan Bangka Belitung maupun oleh Pemerintah Daerah Provinsi Kepulauan Bangka Belitung, upaya yang dilakukan sebagain besar bersifat preventif. Hal ini dilihat dari beberapa upaya yang sudah dilakukan selama ini.

Beberapa upaya sudah dilakukan di Kantor Wilayah Kementerian Hukum dan Hak Asai Manusia Kepulauan Bangka Belitung. Hanya saja, upaya-upaya itu masih sebatas ajakan, misalnya memberikan himbauan kepada masyarakat, pelaku usaha, instansi, untuk tidak membeli dan menggunakan produk yang diduga hasil dari pelanggaran KI, pemantauan oleh Penyidik Pegawai negeri Sipil (PPNS) terhadap dugaan pelanggaran KI di masyarakat dengan melalui koordinasi dengan aparat penegak hukum lainnya. Selain itu, penegakan hukum terhadap tindak pidana di bidang KI pun dilakukan bila ada aduan. ${ }^{47}$ Hal ini tentu tidak menyalahi aturan sebetulnya, sebab sesuai dengan kehendak regulasi di bidang KI yang menyatakan bahwa tindak pidana KI adalah delik aduan.

Selain upaya-upaya tersebut di atas, Kantor Wilayah Kementerian Hukum dan Hak Asai Manusia Kepulauan Bangka Belitung juga melakukan inventarisasi potensi KI, termasuk KI komunal bersumber dari wilayah tertentu, termasuk meningkatkan kerjasama dengan pemerintah daerah, sentra kekayaan intelektual dan komunitas, serta optimalisasi dan pengawasan indikasi geografis yang ada di wilayah Kepulauan Bangka Belitung. Dari tahun 2015-2020, tercatat ada 20 kerjasama yang dijalin oleh Kantor

47 I.C. Siregar, Kepala Bidang Pelayanan Hukum Kantor Wilayah Hukum\& Hak Asasi Manusia Kepulauan Bangka Belitung, FGD, 6 Oktober 2020. 
Wilayah Kementerian Hukum dan Hak Asai Manusia Kepulauan Bangka Belitung, di antaranya dengan Pemerintah Provinsi Kepulauan Bangka Belitung, beberapa pemerintah daerah kabupaten/ kota, perguruan tinggi, Masyarakat Perlindungan Indikasi Geografis (MPIG), dan juga Dewan Perwakilan Rakyat Daerah (DPRD) Provinsi Kepulauan Bangka Belitung. ${ }^{48}$

Upaya-upaya itu, sebagaimana yang disampaikan oleh I.C. Siregar, Kepala Bidang Pelayanan Hukum Kantor Wilayah Kementerian Hukum \& Hak Asasi Manusia Kepulauan Bangka Belitung dalam FGD yang diselenggarakan pada tanggal 6 Oktober 2020, belum cukup mampu meningkatkan pendaftaran KI di Kepualauan Bangka Belitung. Data perlindungan KI di Kepulauan Bangka Belitung tahun 2015-2020, tercatat ada 20 hak cipta, 110 merek, 1 indikasi geografis, 1 desain industri. Sementara itu, tidak tercatat adanya perlindungan terhadap KI jenis pengetahuan tradisional dan ekpresi budaya tradisional.49 Baik pengetahuan tradisional maupun ekspresi budaya tradisioanal, keduanya merupakan aset negara dengan potensi sangat tinggi terhadap kemakmuran bangsa. Hal ini dikarenakan kedua hal ini memiliki nilai ekonomi yang tinggi, hanya saja kepemilikannya banyak oleh asing. ${ }^{50}$

Sementara itu, tidak ada usulan KI yang melewati Pemerintah Provinsi Kepulauan Bangka Belitung dalam hal ini melalui biro hukum. Padahal, Pemerintah Provinsi Kepulauan Bangka Belitung juga sudah melakukan beberapa upaya untuk melindungi KI di daerah ini, tetapi hanya sebatas pemberitahuan dengan mengirim surat kepada Organisasi Perangkat Daerah (OPD) unsuk mengusulkan KI. Upaya yang kurang maksimal ini dilakukan karena tugas pokok dan fungsi biro hukum tidak ada yang menyentuh langsung ke KI, tetapi hanya yang berkaitan dengan peraturan perundangundangan yakni peraturan daerah, jaringan dokumentasi dan informasi hukum (JDIH), dan pelayanan hukum. ${ }^{51}$ Dalam konteks KI, pemerintah daerah memaknai tugas pokok dan fungsi secara sempit. Apabila dimaknasi secara luas, maka fungsi pelayan hukum misalnya melingkupi pula di dalamnya pelayanan terhadap upaya perlindungan KI.

\section{Kesimpulan}

Dalam kaitannya dengan perlindungan KI, beberapa upaya sudah dilakukan oleh Kantor Wilayah Kementerian Hukum dan Hak Asai Manusia Kepulauan Bangka Belitung, di antaranya; (1) memberikan himbauan kepada masyarakat, pelaku usaha, instansi, untuk tidak membeli dan menggunakan produk yang diduga hasil dari pelanggaran KI; (2) pemantauan oleh Penyidik Pegawai negeri Sipil (PPNS) terhadap

48 I.C. Siregar, Kepala Bidang Pelayanan Hukum Kantor Wilayah Hukum\& Hak Asasi Manusia Kepulauan Bangka Belitung, FGD, 6 Oktober 2020.

49 Lihat Penjelasan Pasal 5 huruf e Undang-Undang Nomor 5 Tahun 2017 tentang Pemajuan Kebudayaan dan penjelasan Pasal 38 Ayat (1) Undang-Undang Nomor 28 Tahun 2014 tentang Hak Cipta.

50 Atsar, A. (2017). Perlindungan Hukum Terhadap Pengetahuan dan Ekspresi Budaya Tradisional Untuk Meningkatkan Kesejahteraan Masyarakat Ditinjau Dari Undang-Undang No.5 Tahun 2017 tentang Pemajuan Kebudayaan dan Undang-Undang No.28 Tahun 2014 tentang Hak Cipta. Jurnal Law Reform. 13 (2). doi: https:// doi.org/10.14710/lr.v13i2.16162. p. 289.

51 Harpin, Kepala Pelayanan Hukum Biro Hukum Pemerintah Provinsi Kepulauan Bangka Belitung, FGD, 6 Oktober 2020. 
dugaan pelanggaran KI di masyarakat dengan melalui koordinasi dengan aparat penegak hukum lainnya; (3) penegakan hukum terhadap tindak pidana di bidang KI pun dilakukan bila ada aduan; (4) inventarisasi potensi KI, termasuk KI komunal bersumber dari wilayah tertentu; (5) meningkatkan kerjasama dengan pemerintah daerah, sentra kekayaan intelektual dan komunitas, serta optimalisasi dan pengawasan indikasi geografis yang ada di wilayah Kepulauan Bangka Belitung. Dari tahun 20152020, tercatat ada 20 kerjasama yang dijalin oleh Kantor Wilayah Kementerian Hukum dan Hak Asasi Manusia Kepulauan Bangka Belitung, di antaranya dengan Pemerintah Provinsi Kepulauan Bangka Belitung, beberapa pemerintah daerah kabupaten/ kota, perguruan tinggi, Masyarakat Perlindungan Indikasi Geografis (MPIG), dan juga Dewan Perwakilan Rakyat Daerah (DPRD) Provinsi Kepulauan Bangka Belitung. Hal yang sama juga dilakukan oleh pemerintah Provinsi Kepulauan Bangka Belitung meskipun hanya sebatas pemberitahuan dengan mengirim surat kepada Organisasi Perangkat Daerah (OPD) untuk mengusulkan KI.

\section{Ucapan terima Kasih (Acknowledgments)}

Pada artikel ini, ucapakan terimakasih kami sampaikan kepada Kementerian Riset dan Teknologi/ Badan Riset dan Inovasi Nasional Republik Indonesia, sebab artikel ini merupakan hasil dari penelitian yang didanai pada tahun pendanaan 2020 dengan skim Penelitian Dosen Pemula (PDP), sebagaimana yang tertuang dalam kontak Nomor 035/SP2H/LT/DPRM/2020. Hal serupa juga disampaikan kepada Lembaga Penelitian dan Pengabdian kepada Masyarakat (LPPM) Universitas Bangka Belitung yang sudah memfasilitasi penelitian ini, dan juga kepada Fakultas Hukum dan Fakultas Ekonomi Universitas Bangka Belitung, unit kerja para peneliti.

\section{Daftar Pustaka / Daftar Referensi}

\section{Buku}

Dirdjosisworo, S. (2005). Antisipasi Terhadap Bisnis Curang; Pengalaman Negara Maju Dalam Perlindungan Hak Kekayaan Intelektual (Intellectual Property) dan Pengaturan ECommerce Serta Penyesesuaian Undang-Undang HKI Indonesia. Bandung: CV. Utomo.

Hasibuan, O. (2006). Perlindungan Hak Ekonomi Pencipta Lagu dan Pemegang Hak Terkait di Indonesia (Ringkasan Desertasi). Yogyakarta: Universitas Gadjah Mada.

Kansil, C.S.T. \& Kansil, C.S.T. (2011), Pengantar Ilmu Hukum Indonesia. Jakarta: Rineka Cipta.

Lindsey, T., Damian, E., Butt, S. \& Utomo, T.S. (2013). Hak Kekayaan Intelektual Suatu Pengantar. Bandung: Alumni.

Margono, S. (2010). Hukum Hak Cipta Indonesia; Teori dan Analisa Harmonisasi Ketentuan WTO-TRIPs Agreement. Bogor: Ghalia Indonesia.

Muhammad, A. (2019). Hukum Perdata Indonesia. Bandung: Citra Aditya Bakti.

Nasution, B.J. (2008). Metode Penelitian Ilmu Hukum. Bandung: Mandar Maju.

Nasution, R.J.P. (2017). Interface Hukum Kekayaan Intelektual dan Hukum Persaingan Usaha (Penyalahgunaan HKI). Depok: RajaGrafindo Persada.

Raharjo, S. (2000). Ilmu Hukum. Bandung: Citra Aditya Bhakti.

Riswandi, B.A. dan Syamsudin, M. (2004). Hak Kekayaan Intelektual dan Budaya Hukum. Jakarta: RajaGrafindo Persada. 
Sadikin, OK. (2004). Aspek Hukum Hak Kekayaan Intelektual. Jakarta: Rajagrafindo Persada. Jakarta.

Salim HS. (2016). Pengantar Hukum Perdata Indonesia Tertulis (BW). Jakarta: Sinar Grafika.

Salim HS \& Nurbani, E.S. (2017). Penerapan Teori Hukum Pada Penelitian Tesis dan Disertasi. Jakarta: RajaGrafindo Persada.

Soekanto, S. (2012). Pengantar Penelitian Hukum. Jakarta: UI Press.

Sofwan, S.S.M. (2000). Hukum Perdata: Hukum Benda. Yogyakarta: Liberty.

Syahrani, R. (2013). Seluk-Beluk dan Asas-Asas Hukum Perdata. Bandung: Alumni.

Tutik, T.T., (2015), Hukum Perdata Dalam Sistem Hukum Nasional, Jakarta: Kencana.

\section{Jurnal \& Prosiding}

Anggraeni, D. \& Ahmad, P. (2018). Upaya Perlindungan Hukum Terhadap Indikasi Geografis di Kota Tangerang Selatan untuk Mengembangkan Ekonomi Masyarakat Lokal. Prosiding Seminar Ilmiah Nasional “Kearifan Lokal Untuk Menjawab Tantangan Global". 27-28 Oktober 2018.

Atsar, A. (2017). Perlindungan Hukum Terhadap Pengetahuan dan Ekspresi Budaya Tradisional Untuk Meningkatkan Kesejahteraan Masyarakat Ditinjau Dari Undang-Undang No.5 Tahun 2017 tentang Pemajuan Kebudayaan dan UndangUndang No.28 Tahun 2014 tentang Hak Cipta. Jurnal Law Reform. 13 (2). doi: https:// doi.org/10.14710/lr.v13i2.16162.

Babutta, S.L., (2020), Memaknai Manusia dalam Dimensi Mahluk Hidup: Kajian Filosofis dari Sudut Pandang Biologi, Jumal Filsafat Indonesia, 3 (2), doi: http://dx.doi.org/10.23887/ifi.v3i2.22512.

Darwance, Yokotani, \& Anggita, W. (2020). Dasar-Dasar Perlindungan Hak Kekayaan Intelektual. Progresif: Jurnal Hukum. 15 (2). doi: https://doi.org/10.33019/progresif.v15i2.1998.

Darwance, Yokotani, \& Anggita, W. (2021). Politik Hukum Kewenangan Pemerintah Daerah Dalam Pengaturan Hak Kekayaan Intelektual. Journal of Political Issues. 2 (2). doi: https:// doi.org/10.33019/jpi.v2i2.40.

Darwance, Nugroho. S., \& Yokotani. (2018). Pengaturan Komoditas Lada di Provinsi Kepulauan Bangka Belitung Perspektif Asas-Asas Pembentukan Peraturan Perundang-Undangan. Jurnal Kertha Patrika. 40 DOI: https://doi.org/10.24843/KP.2018.v40.i01.p01.

Galih, Y.S. (2017). Kewajiban Negara Melindungi Anak Bangsa. Jurnal Nasional Galuh Justisi. 5 (1). doi: http://dx.doi.org/10.25157/jigj.v5i1.249.

Harpin, Kepala Pelayanan Hukum Biro Hukum Pemerintah Provinsi Kepulauan Bangka Belitung, FGD, 6 Oktober 2020.

I.C. Siregar, Kepala Bidang Pelayanan Hukum Kantor Wilayah Hukum\& Hak Asasi Manusia Kepulauan Bangka Belitung, FGD, 6 Oktober 2020.

Karim. A dan Dayanto. (2016). Perlindungan Hukum dan Pengembangan Indikasi Geografis Minyak Kayu Puth di Pulau Buru. Jurnal RechtsVinding. 5 (3). doi: http://dx.doi.org/10.33331/rechtsvinding.v5i3.151. 
Mahardhita, Y \& Sukron, A.Y. (2018). Perlindungan Hukum Hak Kekayaan Intelektual Melalui Mekanisme "Cross Border Measure". Jurnal Ilmiah Ilmu Hukum QISTIE. 11 (1). doi: http://dx.doi.org/10.31942/jqi.v11i1.2227.

Mike, E. (2017). Perlindungan Hukum Hak Kekayaan Intelektual Terhadap Tindakan Pelanggaran Pembajakan Buku Elektronik Melalui Media Online. AL-IMARAH: Jurnal Pemerintahan dan Politik Islam. 2 (2). doi: http://dx.doi.org/10.29300/imr.v2i2.1449.

Nizwana, Y. \& Rahdiansyah. (2019). Perlindungan Hak Kekayaan Intelektual (HAKI) Ditinjau Dari Epistimologi. UIR Law Review. 3 (2), doi: https://doi.org/10.25299/uirlrev.2019.vol3(02).4006.

Nurhaini, S. (2017). Perlindungan Hak Cipta Atas Ekspresi Budaya Tradisional Pada Kerajinan Tangan di Provinsi Kepulauan Bangka Belitung, Progresif: Jurnal Hukum. 10 (1). doi: https:// doi.org/10.33019/progresif.v11i1.195.

Nurdahniar, I. (2016). Analisis Penerapan Prinsip Perlindungan Langsung Dalam Penyelenggaraan Pencatatan Ciptaan. veritas et Justitia. 2 (1). doi: https://doi.org/10.25123/vej.v2i1.2073.

Sari, N.K. \& Susanti, D.O, Perlindungan Hukum Bagi Pemilik Karya Cipta Batik Tulis Dewi Rengganis di Desa Jatiurip Kecamatan Krejengan Kabupaten Probolinggo. SASI. 24 (2). doi: https://doi.org/10.47268/sasi.v24i2.127.

Umami, Y.Z. \& Roisah. K. (2015). Perlindungan Hukum Terhadap Kelapa Kopyor Sebagai Potensi Komoditas Indikasi Geografis Kabupaten Pati. Jurnal Law Reform. 11 (1). doi: https:// doi.org/10.14710/lr.v11i1.15760.

Yuhaswita, (2016), Akal, Manusia dan Kebudayaan, Tsaqofah \& Tarikh, 1 (1), doi: http://dx.doi.org/10.29300/ttjksi.v1i1.861.

\section{Tesis}

Panduwinata, B. (2013). Perlindungan Hukum Hak Cipta Bagi Pengarang Buku (Legal Protection Of The Copyright For The Author Of The Book) (Tesis). Program Pascasarjana Magister Kenotariatan Universitas Hasanuddin Makassar.

\section{Online/World Wide Web:}

Lihat di www.dgip.go.id, (Diakses 09 Maret 2021).

Polda Babel Tangani 5 Kasus Pelanggar Hak Cipta.. Lihat di https://www.radarbangka.co.id/berita/detail/kamtibmas/28739/polda-babel-tangani-5kasus-pelanggar-hak-cipta.html, (Diakses 18 Mei 2021).

Gara-Gara Video Wisata Bos Ini Tersangka Kasus Hak Cipta. Lihat di https://nasional.tempo.co/read/850151/gara-gara-video-wisata-bos-initersangka-kasus-hak-cipta, (Diakses 18 Mei 2021). 